\title{
Mineralogical and microbial correlation of phosphate ore mine in Hazm Al-Jalamid
}

\author{
Sultan Alsagabi ${ }^{* 1}$, Majed Albokari ${ }^{1}$, Ibrahim Mashhour ${ }^{1}$ \\ ${ }^{1}$ King Abdulaziz City for Science \& Technology (KACST), P. O. Box 6086, Riyadh 11442, Saudi Arabia
}

\begin{abstract}
This environmental engineering study was conducted to investigate and correlate the fundamental mineralogical compositions of phosphate rock in the Hazm Al-Jalamid area of Saudi Arabia at different layers originating from an open-pit mine. Microbial communities within these layers and the associated correlations between the mineralogical compositions at different geological and textural profiles were investigated. Three representative phosphaterock layers, upper, middle, and lower, were investigated. The dominated crystal structure of the upper layer was calcite, while dolomite, and quartz were in middle and lower layers, respectively. In contrast, Phosphate concentrations reached levels around 3.12\%, 7.66\%, and $3.92 \%$ of the overall content of representative samples in the upper, middle, and lower layers, respectively. The same trends were observed for both fluorapatite and phosphorus pentoxide. The microbiome of the phosphate-ore samples was evaluated. The phylum Proteobacteria dominated the upper and middle layers, while the well-known phosphate-solubilizing bacteria species Pseudomonas putida were present at $46 \%$ and $50 \%$ in both the upper and middle layers, respectively. In contrast, the actinobacterium Saccharopolyspora flava dominated the lower layer. Increasing selective phyla and species that associated with the elevated content of phosphorus from one layer to another within mine enhanced the understating of these
\end{abstract} microorganisms as extremophiles.

\section{Background}

Saudi Arabia is among the most economically important countries worldwide, particularly because of its (1) different sources of mine ores and deposits and (2) phosphate deposits in the northern region in Al-Jalamid area [1-2]. New mining activities have recently been started in Hazm Al-Jalamid in the northern region of Saudi Arabia to explore phosphate ores useful for manufacturing diammonium phosphate and/or monoammonium phosphate or natural slow-releasing rock phosphate fertilizers [1-2]. This mine is considered as an open-pit mine and is more than $10 \mathrm{~m}$ in depth. The details of the site have been described in an investigation of the geochemistry and origin of phosphorite deposits at the Hazm Al-Jalamid area along with environmental impact assessment [1-2]. Deposited available phosphates on Earth include marine, igneous, metamorphic, weathered, and/or biogenic deposits, with phosphate rock deposits as the most abundant source of phosphorus worldwide. Phosphate rock deposits have a wide range of uses in the agricultural and chemical industries.

For practical applications, the quality and concentration of phosphate ore must be measured and evaluated to determine its physical and chemical properties [1-2]. For instance, the presence of heavy and trace elements along with various compounds can alter the main composition of these phosphate rocks. The dominate crystal structure and phosphate concentration can be investigated using different phosphate rocks in different geologic and textural profiles. As an essential nutrient, phosphorous is also involved in numerous key biochemical reactions, e.g., photosynthesis, respiration, energy storage and transfer, and other vital processes in nearly all living organisms. Some biological properties and processes involving phosphate minerals occur in mines; therefore, investigating these parameters may serve as proxies for ecological stress and for determining the primary function of phosphate in the formation of mines, ore, and deposits. Phosphate are also major components of DNA and the structural constituent of nucleic acids, phytin, and phospholipids, and thus have important biological functions [3].

In general, the microbial community in ecological resources containing phosphate such as gypsum and phosphate-ore mine can be isolated or detected to be utilized for novel applications such as in the development of new biotechnological processes or fertilizer production as part of phosphate processing. In rich-phosphate soil or matrix, some microorganisms can mediate carbonate to utilize phosphorous. Therefore, microbial communities that inhibit ecological systems may have elevated levels of certain elements and the quality of phosphate may depend on microbe-mediated processes. The microbial community structure has been

* Corresponding author: dr.alsagabi@gmail.com 
suggested as an indicator of phosphate solubilization. Generally, different layers of open-pit mines are associated with different elemental compositions and compounds. Therefore, the indigenous microbial community structure along with individual microorganisms in the phosphate mine may serve as sensitive quality and quantity indicators because of the strong correlation, integration, and dependency of the biomass habitat with the existing nutritional surroundings. Studies of the colorations of different layers (depth) and microbial communities inhabiting the Hazm Al-Jalamid mine have been limited. This study was conducted to investigate the fundamental mineralogical compositions of different layers of phosphate rock originating from the open-pit mine in the Hazm Al-Jalamid area. The elemental composition and bacterial communities associated with these crystals were evaluated to determine their correlation with the phosphate concentration and other mineral compounds in the phosphate-ore mine.

\section{Materials and Methods}

\subsection{Sampling site and collection}

From an industrial perspective, geologists and mine workers classify mines into upper (waste), middle (soft), and lower (hard) layers. Each layer can be identified based on the layer nature and ore concentration, among other visual and experimental characteristics. Samples in this study were collected from the Hazm Al-Jalamid area $\left(39^{\circ} 19^{\prime} 39.06^{\prime \prime} \mathrm{E}-31^{\circ} 31^{\prime} 12.57^{\prime \prime} \mathrm{N}\right)$ in the northern region of Saudi Arabia. Hazm Al-Jalamid is an open-pit phosphate mine and three phosphate-rock samples were collected from each of the three layers facing the internal wall of the mine, as shown in Figure 1. Three replicate samples were collected from each layer into plastic sterile tubes with screw caps. The samples from each layer were gently ground in an anaerobic cabinet to prevent contamination. Each sample was divided into two aliquots, one for geo-analysis of parameters and the mineralogical compositions, which was stored at room temperature, while the other was used for DNA extraction and bacterial profiling and kept in a freezer at $-80^{\circ} \mathrm{C}$.

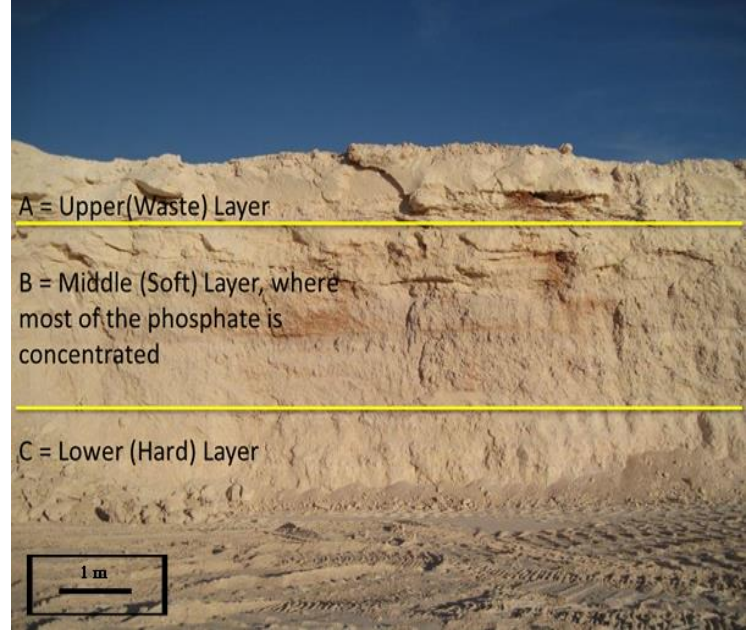

Fig 1. Sampling site of open phosphate ore mine.

\subsection{Analysis of mineralogical and microbial composition}

The mineralogical compositions (quartz, fluorapatite, calcite, and dolomite) of phosphate-rock from the openpit mine were determined by X-ray diffraction (XRD) using a Philips PW1729 X-ray diffractometer (Amsterdam, Netherlands) with a graphite monochromator. X-Ray fluorescence was performed for multi-element analysis (i.e., $\mathrm{Ca}, \mathrm{Mg}, \mathrm{Si}, \mathrm{P}$ ) using a Siemens SRS3000 wavelength-dispersive X-ray fluorescence spectrometer (Munich, Germany) equipped with a $3-\mathrm{kW}$ rhodium end-window tube and Siemens SpectraPlus software.

Each sediment sample ( $0.25 \mathrm{~g})$ was subjected to bacterial identification and analysis. Genomic DNA was extracted using a PowerSoil DNA Isolation Kit (Mo Bio Laboratories, Inc., Carlsbad, CA, USA) according to the manufacturer's instructions. The concentration of the extracted DNA was quantified using Nanodrop 1000 spectrophotometer (Thermo Fisher Scientific, Waltham, MA, USA). PCR, purification, and sequencing of DNA were carried out in a Mr. DNA Lab (Molecular Research LP, Shallowater, TX, USA). PCR amplicon sequencing for 454 pyrosequencing was performed using bTEFAP ${ }^{\circledR}$ as described by [4-5]. The 454 pyrosequencing technique, performed in a Roche 454 FLX titanium instrument (Basel, Switzerland), is a high-throughput DNA sequencing method that uses single-strand DNA with a length of $400-500$ base pairs (bp). All DNA samples were adjusted to $100 \mathrm{ng} / \mu \mathrm{L}$, and $100 \mathrm{ng}(1 \mu \mathrm{L})$ aliquots of each sample were used for in each $50-\mu \mathrm{L}$ PCR sample. Forward and reverse $16 \mathrm{~S}$ universal eubacterial primers 515F (GTGCCAGCMGCCGCGGTAA) and 806R (GGACTACHVGGGTWTCTAAT) for bacteria were used in a single-step 30-cycle PCR. PCR amplification was performed using a HotStarTag plus Master Mix Kit 
(Qiagen, Hilden, Germany) under the following conditions: $94^{\circ} \mathrm{C}$ for $30 \mathrm{~min}$, followed by 28 cycles of $94^{\circ} \mathrm{C}$ for $30 \mathrm{~s}, 53^{\circ} \mathrm{C}$ for $40 \mathrm{~s}, 72^{\circ} \mathrm{C}$ for $1 \mathrm{~min}$, and then for a final elongation step at $72^{\circ} \mathrm{C}$ for $5 \mathrm{~min}$. All amplicon products from different samples were mixed in equal concentrations and purified using Agincourt Ampure beads (Agincourt Bioscience Corporation, Beverly, MA, USA), followed by PCR.

Sequence data were processed using a proprietary analysis pipeline owned by Molecular Research Lab. Briefly, the following sequences were removed: sequences assigned barcodes and primers shorter than $200 \mathrm{bp}$, sequences with ambiguous base calls, and sequences with homopolymer runs exceeding $6 \mathrm{bp}$. Finally, chimeras were removed after denoising the sequences. After removing singleton sequences, operational taxonomic units (OTUs) were defined and clustered at 3\% divergence. Taxonomic classification of the OTUs obtained was conducted by BLASTn searches against a curated Greengenes/RDP/NCBI-derived database and compiled into each taxonomic level [6]. A compact package of different statistical analyses including XLstat, NCSS 2007, "R", and NCSS 2010 was used. Alpha and beta diversity analysis was conducted using Qiime [7]. A $\mathrm{p}<0.05$ was considered to indicate significance for all analyses. A dual hierarchal dendrogram was constructed to provide a visual overview of a combined heatmap for predominant genera and connection lines as clusters with more similar consortium of genera based on matching similarity. The overall phylogenetic distance was determined by Jackknife for the OTU data showing the biodiversity among bacterial communities. Fast UniFrac and principal coordinate analysis images were captured to evaluate differences in the microbiota [8]. UniFrac principal coordinate analyses for the three principal coordinates (PCs) were weighted as UniFrac values with $\mathrm{PC} 1=89.86 \%, \mathrm{PC} 2=0.0 \%$, and PC3 $=10.14 \%(\mathrm{p}=$ $0.001)$.

\section{Results}

\subsection{Mineralogy and their associated elements in open-pit mine rock phosphate}

Phosphate rock in an open-pit ore mine is comprised of various mineral phases (quartz, fluorapatite, calcite, dolomite ...etc.) along with different oxides and trace/rare elements. The XRD patterns and associated mineral phases were evaluated and the nominal composition in quantitative-qualitative form for the major compounds and elements in the mine samples are shown in Table 1 and the analysis showed that the fluorapatite $(\mathrm{Ca} 5(\mathrm{PO} 4) 3 \mathrm{~F})$ and calcite $(\mathrm{CaCO} 3)$ crystal structures were present in all three layers, dolomite $(\mathrm{CaCO} 3 \cdot \mathrm{MgCO} 3)$ was in the middle and lower layers, while quartz was only in the lower layer. The chemical composition of the upper and middle layers was predominated by $\mathrm{Ca}$ and $\mathrm{P}$. However, $\mathrm{Si}$ was predominate in the lower layer at more than $27 \mathrm{wt} . \%$, as shown in Table 1.

The results revealed well-developed crystals and mineral phases with commercial value associated with mineral elements at the quality and quantity level, Table 1 . Thus, the waste layer contained large amounts of calcite (81\%) and fluorapatite (19\%) along with different oxides such as $\mathrm{P} 2 \mathrm{O} 5$ (5.29\%), $\mathrm{MgO}(11.27 \%), \mathrm{SiO} 2$ (0.48\%), and $\mathrm{CaO}(42.16 \%)$. The middle layer contained the highest amount of economically important dolomite (61\%) followed by fluorapatite $(30 \%)$ and calcite $(9 \%)$ along with other important compounds, including P2O5 (17.96\%), $\mathrm{MgO}(2.41 \%), \mathrm{SiO} 2(0.31 \%)$, and $\mathrm{CaO}$ $(57.76 \%)$. In contrast, the lower layer contained relatively less dolomite $(6 \%)$ but the largest amount of quartz $(49 \%)$, considerable amounts of fluorapatite $(24 \%)$ and calcite $(21 \%)$, and substantial amounts of $\mathrm{P} 2 \mathrm{O} 5$ (14.94\%), $\mathrm{MgO}(4.31 \%), \mathrm{SiO} 2(0.69 \%)$, and $\mathrm{CaO}$ $(53.76 \%)$. Notably, dolomite, an anhydrous carbonate mineral composed of calcium magnesium carbonate and fluorapatite, as well as phosphate mineral dominated the middle layer. This was confirmed by an increase in phosphorus pentoxide (P2O5) in the middle layer. The other results are listed in Table 1.

Table 1. Quantitative contents of major compounds and elements in different layers of an open phosphate ore mine

\begin{tabular}{|c|c|c|c|}
\hline & $\begin{array}{c}\text { Upper } \\
\text { layer } \\
\text { (Waste) }\end{array}$ & $\begin{array}{c}\text { Middle } \\
\text { layer } \\
\text { (Soft) }\end{array}$ & $\begin{array}{c}\text { Lower } \\
\text { layer } \\
\text { (Hard) }\end{array}$ \\
\hline $\mathrm{P}_{2} \mathrm{O}_{5} \%$ & 5.29 & 17.96 & 14.94 \\
\hline $\mathrm{CaO} \%$ & 42.16 & 57.18 & 53.76 \\
\hline $\mathrm{MgO} \%$ & 11.27 & 2.41 & 4.31 \\
\hline $\mathrm{SiO}_{2} \%$ & 0.48 & 0.31 & 0.69 \\
\hline $\mathrm{P} \%$ & 3.12 & 7.66 & 3.92 \\
\hline $\mathrm{Ca} \%$ & 64.2 & 34.5 & 18.2 \\
\hline $\mathrm{Mg} \%$ & 0.28 & 4.94 & 0.55 \\
\hline $\mathrm{Si} \%$ & 0.10 & 0.11 & 27.3 \\
\hline $\begin{array}{c}\text { Dolomite \% - } \\
\mathrm{CaMg}(\mathrm{CO})_{2}\end{array}$ & --- & 61 & 6 \\
\hline $\mathrm{Calcite} \%-\mathrm{CaCO}_{3}$ & 81 & 9 & 21 \\
\hline $\begin{array}{c}\text { Fluorapatite \% - } \\
\mathrm{Ca} 5\left(\mathrm{PO}_{4}\right)_{3} \mathrm{~F}\end{array}$ & 19 & 30 & 24 \\
\hline Quartz \% - $\mathrm{SiO}_{4}$ & --- & --- & 49 \\
\hline
\end{tabular}

\subsection{Microbial communities associated with phosphate rock open-pit mine}

After stringent quality sequence curation, 18,449 sequences were parsed and 11,404 were clustered. A total of 11,346 sequences identified as bacteria or archaea were used for the final analyses. The average number of reads per sample was 3,801. For alpha and beta diversity analysis, samples were rarefied to 1000 sequences and bootstrapped at 800 sequences. Table 2 summarizes the number of sequences and OTUs at $97 \%$ similarity, as well as the diversity indices for bacteria. 
Table 2. Number of reads, operational taxonomic units at $97 \%$ similarity, and diversity indices for revealed bacteria

\begin{tabular}{|c|c|c|c|c|}
\hline Sample & No. of reads & OTUs & Chao1 & Shannon \\
\hline A (Upper) & 2,469 & 89 & 122 & 3.05 \\
\hline B (Middle) & 3,049 & 129 & 169 & 3.36 \\
\hline C (Lower) & 5,886 & 109 & 134 & 3.18 \\
\hline
\end{tabular}

The Shannon and Chaol statistical indices and OTUs indicated differences among the three samples. However, samples from the middle layer were the most diverse (3.36) and showed the highest richness (169) as indicted by the Shannon and Chaol indices, respectively. A threshold of more than $5.0 \%$ was considered when constructing the microbial communities of the three layers. The most predominant phyla identified in the mine and across layers were Proteobacteria and Actinobacteria with averages among the three layers of $56 \%$ and $33 \%$, respectively (Figure 2). The former was detected in the upper layer with a value of $87 \%$, while the latter was detected in the lower layer with a value of $92 \%$.

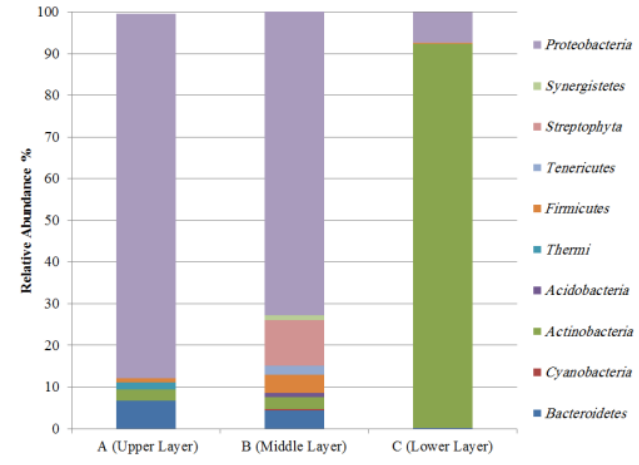

Fig 2. Bacterial phyla of the three layers of the phosphate ore mine.

A dual hierarchal dendrogram was constructed (Figure

3) to provide a visual overview of the combined heatmap for predominant genera and connection lines as clusters for the three layers based on matching similarity. The lower layer (sample C) was separate from the combination of the upper (sample A) and middle layers (sample B), indicating a significant difference between the two clusters. Moreover, at the genus level, Pseudomonas and Herbaspirillum showed the highest levels in the upper and middle layers with average percentages of $44 \%$ and $15 \%$, respectively, for the upper layer (A) and average percentage of $46 \%$ and $5 \%$, respectively, for the middle layer (B). In contrast, Amycolatopsis and Saccharopolyspora predominated the lower layer with $47 \%$ and $35 \%$, respectively. Pseudomonas was present in the lower layer at only $5 \%$.

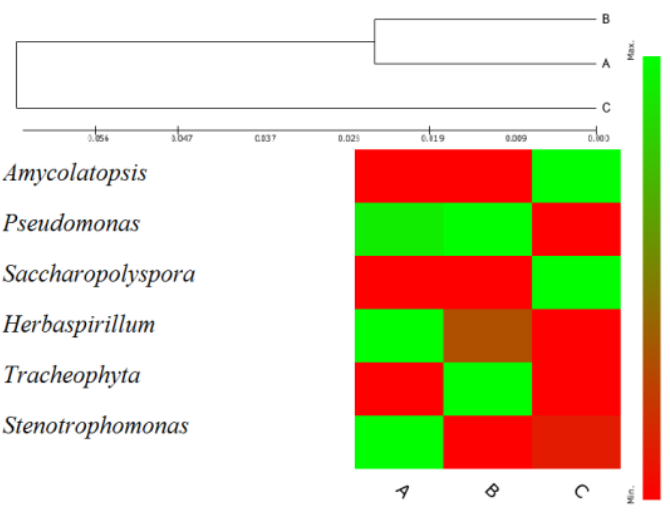

Fig 3. Bacteriological analysis of the total bacterial content in the: A) waste (upper), B) soft (middle), and C) hard (lower) layers of the phosphate rock open-pit mine.

\section{Discussion}

The quality of phosphate-rock as a fertilizer generally depends on its age, particle size, degree of substitution in the crystal structure, and solubility in acids. The samples evaluated in the present study showed acceptable quality and quantity (Table 1), indicating the potential of these materials as phosphate fertilizer and liming materials for acid soil correction. Our results agreed well with those of demonstrated in [9], who reported that the typical chemical composition of phosphate-rock is predominantly $\mathrm{P} 2 \mathrm{O} 5$ and $\mathrm{CaO}$ and in the range of 29-54 wt.\% and 24-40 wt.\%, respectively. In contrast, a study of a Moroccan phosphate mine showed that the concentrations of $\mathrm{P} 2 \mathrm{O} 5$ and $\mathrm{CaO}$ were approximately 26.4 and 40.9 wt.\%, respectively [10]. P2O5 naturally exists at $15-35 \%$ in phosphate-rock; in previous studies at this site, Aissa et al. found ranges of $24.73-33.20 \%$ and $54.57-48.90 \%$ for $\mathrm{P} 2 \mathrm{O} 5$ and $\mathrm{CaO}$, respectively, while Al-Hobaib et al. recorded ranges of 3.22-27.34\% and $9.93-70.42 \%$, respectively, as shown in Table 3 [12]. Our results for $\mathrm{P} 2 \mathrm{O} 5$ and $\mathrm{CaO}$ in the three layers laid agreed with those of Al-Hobaib et al., while only the results for $\mathrm{CaO}$ matched those of Aissa et al. [1-2]. Thus, the percentage and concentration of phosphorus in this study agreed with earlier results showing a range of $1.40-11.9 \%$ [2]. The same trends were observed for calcium (7.1-50.2\%) and magnesium (0.04-7.93\%) (Table 3). Notably, previous studies of this open-pit-ore mine did not specify the sampling layer or depth beneath the surface, which may explain the variations in individual constituents among previous studies and the current study (Table 3 ). This is the first study to evaluate the percentage of mineral phases, oxides, and elements in the three layers of the internal wall of open-pit ore mine beneath the rock surface to determine the correlation between the phosphate rock crystals and microbial community. Rock phosphate is a natural material typically used to produce phosphorus fertilizers; the fertilizer grade can be utilized to investigate other characteristics. The phosphorus content of phosphaterock, P2O5, and principal minerals containing Caphosphates, such as fluorapatite, are commercially 
valuable for phosphorus fertilization and for liming to correct soil acidity. Moreover, microbial solubilization of phosphate-rock is an alternative environmentally approach comparing to chemical treatment [11]. Microbes can partially acidulate phosphate rock system; however, isolation and detection of mineral phosphatesolubilizing bacteria from phosphate-rock mines can be considered as an environmentally friendly process for fertilizer production [12]. The correlation between mineral crystals and their associated solubilizing bacteria in a phosphate mine may indicate an elevated level of phosphate.

Table 3. Mineralogical characteristics of phosphate rock from different layers the open-pit phosphate ore mine

\begin{tabular}{|c|c|c|c|c|c|}
\hline & \multicolumn{3}{|c|}{ This study } & \multirow{2}{*}{$\begin{array}{c}\begin{array}{c}\text { Aissa } \\
\text { et } \\
\text { al.(2014) }\end{array} \\
\text { Av }\end{array}$} & \multirow{2}{*}{$\begin{array}{c}\begin{array}{c}\text { Al- } \\
\text { Hobaib } \\
\text { et }\end{array} \\
\text { al.(2013) } \\
\text { Av }\end{array}$} \\
\hline & $\begin{array}{c}\mathrm{Up} \\
\text { layer }\end{array}$ & $\begin{array}{l}\text { Mid. } \\
\text { layer }\end{array}$ & $\begin{array}{l}\text { Low } \\
\text { layer }\end{array}$ & & \\
\hline $\mathrm{P}_{2} \mathrm{O}_{5} \%$ & 5.3 & 17.9 & 14.9 & 29.1 & 13.3 \\
\hline $\mathrm{CaO} \%$ & 42.1 & 57.1 & 53.7 & 51.5 & 46.8 \\
\hline $\mathrm{MgO} \%$ & 11.2 & 2.4 & 4.3 & 1.4 & 1.5 \\
\hline $\mathrm{SiO}_{2} \%$ & 0.4 & 0.3 & 0.6 & 1.2 & 18.4 \\
\hline $\mathrm{P} \%$ & 3.1 & 7.6 & 3.9 & 12.7 & 5.8 \\
\hline $\mathrm{Ca} \%$ & 64.2 & 34.5 & 18.2 & 36.8 & 33.5 \\
\hline $\mathrm{Mg} \%$ & 0.2 & 4.9 & 0.5 & 0.7 & 0.9 \\
\hline Si \% & 0.10 & 0.1 & 27.3 & 0.5 & 8.6 \\
\hline $\begin{array}{c}\text { Dolomite \% } \\
- \\
\mathrm{CaMg}_{\left(\mathrm{CO}_{3}\right)_{2}}\end{array}$ & --- & 61 & 6 & 12.18 & --- \\
\hline $\begin{array}{c}\text { Calcite \% - } \\
\mathrm{CaCO}_{3}\end{array}$ & 81 & 9 & 21 & 30.85 & --- \\
\hline $\begin{array}{c}\text { Fluorapatite } \\
\%- \\
\mathrm{Ca} 5\left(\mathrm{PO}_{4}\right)_{3} \mathrm{~F}\end{array}$ & 19 & 30 & 24 & 54.58 & --- \\
\hline $\begin{array}{c}\text { Quartz \% - } \\
\mathrm{SiO}_{4}\end{array}$ & --- & --- & 49 & 2.08 & --- \\
\hline
\end{tabular}

There is a strong correlation between inhabiting microorganisms in rocky and hyperarid environmental ecologies and dynamic processes such as the transparency of evaporites minerals and hygroscopic nature of halite and mineral deliquescence [13-15]. Such processes depend on the condensation of vapor water on the crystal surface and/or between crystals and leaving behind favorable microniches for specialized bacteria or archaea [13]. Additionally, these correlations were observed in geological sites and old sedimentary rocks, similarly, in extreme environments, microorganisms obtain their energy from carbonate compounds and different nutrient elements for enzymatic activities [16]. In the present study, pyrosequencing of phosphate-ore mine indicated that the Proteobacteria phylum dominated the upper and middle layers, showing similar values as this phylum isolated from phosphate-rich soil around Dianchi Lake, Kunming, Yunnan Province, and China, which has been suggested as one of the largest basins of P-mines in China [17]. Members of the Actinobacteria phylum dominated the lower layer of the mine, exceeding the levels of the same phylum isolated from a phosphate mine in Togo by six-fold, which was more than the total bacterial profile in Figure 4 [18]. Furthermore, six other phyla, Bacteroidetes, Firmicutes, Tenericutes, Acidobateria, Snergistetes, and Thermi, were scattered and distributed mainly between the upper and middle layers and were in low abundance and nonsignificant compared to Proteobacteria and Actinobacteria.

The bacterial profiles clearly shifted along with mineralogical components among the three layers of the studied mine. Pseudomonas putida predominated the upper and middle layers because of the preferable niches rich in phosphate and magnesium compared to the lower layer (Figure 4). However, the available crystals, calcite, fluorapatite, and dolomite were abundant and may be useful as energy sources. In contrast, the major mineral composition in the lower layer was quartz ( $\mathrm{SiO} 2)$, which was reported as an energy source and suitable environment for Saccharopolyspora spp. [19]. Saccharopolyspora flava represented $36 \%$ of the total bacterial profile in the lower layer because of the preferable niche rich in $\mathrm{SiO} 2$. Figure 4 shows all species detected. Many researchers have suggested that Pseudomonas putida are prime microbes for phosphate solubilization from phosphate-rock [3, 20-22]. Reyes et al. determined the diversity of phosphate-rock solubilizing-bacteria between phosphate-rock mine soil and unmined soil in Venezuela and found that phosphate solubilizing bacteria were significantly abundant in the soil of the mine (19\% of total bacteria) compared to in unmined soil $(5 \%$ of total bacteria) [23]. Correspondingly, Hamdali et al. reported that the main phosphate-solubilizing bacteria were Pseudomonas spp. isolated from four phosphate-rock soil samples of Hahotoé-Kpogamé phosphate mine in Togo and representing $7.52-30.26 \%$ of the total bacteria, which agrees well with our investigated samples [18]. The different layers of the Hazm Al-Jalamid open-pit mine showed mineralogical differences in different layers, and the bacterial communities associated with these layers were identified.

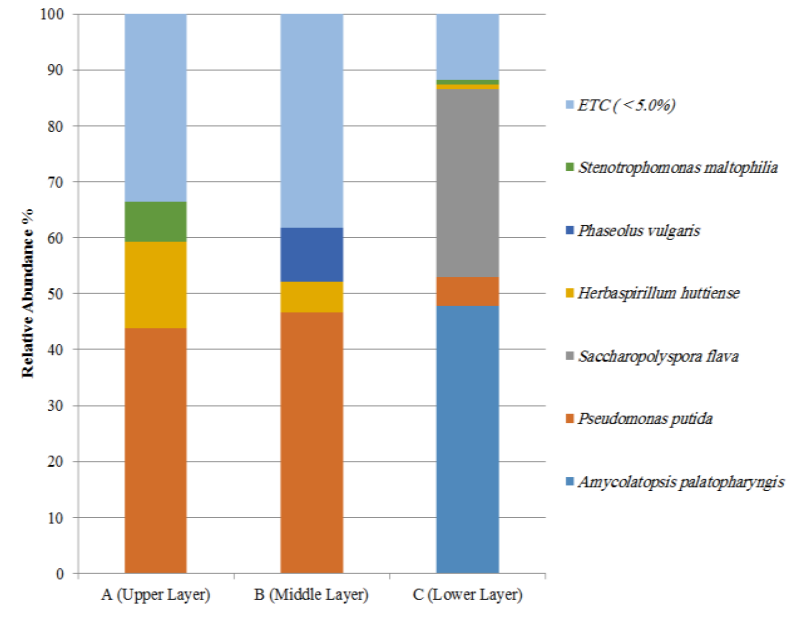


Fig 4. Bacterial species of the three layers of the phosphate ore mine.

\section{Conclusion}

The environmental assessment for different dominating minerals within the phosphate mines in the Hazm AlJalamid area in northern Saudi Arabia were evaluated for coloration assessment. Minerals such as dolomite, calcite, quartz, fluorapatite, and their associate chemical components are the sole source of energy for the microbial consortium to ensure their survival and metabolism activities under the extreme conditions. A suitable environment has been widely detected in existing phosphate rocks of open-pit mine ore. P2O5dominated the middle layer along with both dolomite and fluorapatite. In rich-phosphate soil or matrixin the middle layer containing promising microorganisms such as $\mathrm{P}$. putida, carbonate may be mediated by the solubilization of phosphorous. It is wellknown that the quality of phosphate largely depends on microbe-mediated processes. Moreover, the microbial community structure may provide an early indication of phosphate solubilization. The preferable niches of rich phosphate and magnesium enhanced the presence of $P$. putida among the upper and middle layers. In contrast, Saccharopolyspora spp. dominated the lower layer, as quartz has been widely reported as an energy source and suitable environment for Saccharopolyspora.

\section{References}

1. A. Aissa, A. Abdeen, M. Abualreish, Int. J. Basic. Appl. Sci. 3, 190 (2014)

2. A. Al-Hobaib, H. Baioumy, M. Al-Ateeq, J. Geochem. Explor. 132, 15 (2013)

3. A.E. Richardson, J.M. Barea, A.M. McNeill, C. Pringet-Combaret, Plant Soil. 321, 305 (2009)

4. S.E. Dowd, Y. Sun, R.D. Wolcott , A. Domingo, J.A. Carroll, Foodborne Pathog. Dis. 5, 459 (2008)

5. S.E. Dowd, T.R. Callaway, R.D. Wolcott, Y. Sun, T. McKeehan, R.G. Hagevoort, T.S. Edrington, BMC Microbiol. 8, 125 (2008)

6. T.Z. DeSantis, P. Hugenholtz, N. Larsen, M. Rojas, E.L. Brodie, K. Keller, G.L.Andersen, Appl. Environ. Microbiol. 72, 5069 (2006)

7. K.S. Swanson, S.E. Dowd, J.S. Suchodolski, I.S. Middelbos, B.M. Vester, K.A.Barry, K.E. Nelson, M. Torralba, B. Henrissat, P.M. Coutinho, et al. ISME J. 5, 639 (2011)

8. M. Hamady, C. Lozupone, R. Knight. ISME J. 4, 17 (2010)

9. P. Becker, Phosphates and phosphoric acid: Raw materials, technology, and economics of the wet process (Fertilizer science and technology series, New York, 1983)

10. C. Berish, Potential environmental hazards of phosphogypsum storage in central Florida (The 3rd International Symposium on phosphogypsum, Orlando, 1990)
11. N. Vassilev, M. Vassileva, Appl. Microbiol. Biotechnol. 61, 435 (2003)

12. M.B. Farhat, A. Farhat, W. Bejar, R. Kammoun, K. Bouchaala, A. Fourati, H. Antoun, S. Bejar, H. Chouayekh, Arch. Microbiol. 191, 815 (2009)

13. N. Stivaletta, Mem. S.A.It. Suppl. 16, 106 (2011)

14. A. Davila, B.G. Silva, A. Rios, C. Ascaso, H. Olivares, C.P. McKay, J. Wierzchos, J. Geophys. Res. 113, G01028 (2008)

15. A.F. Davila, I. Hawes, J. Araya, D. Gelsinger, J. Ruggiero, C. Ascaso, J. Wierzchos, Front Microbiol. 6, 1035 (2015)

16. T.R. Bontognali, A. Sessions, A. Allwood, W. Fischer, J. Grotzinger, R. Summons, J. Eiler, Proc. Natl. Acad. Sci. USA. 109, 15146 (2012)

17. P.X. Yang, L. Ma, M.H. Chen, F. Xi, J. He, C.Q. Duan, M. Mo, D. Fang, Y.Q. Duan, F.X. Yang, Pedosphere. 22, 707 (2012)

18. H. Hamdali, K. Moursalou, G. Tchangbedji, Y. Ouhdouch, M. Hafidi. Afr. J. Biotechnol. 11, 312 (2012) 19. Z. Lu, Z. Liu, L. Wang, Y. Zhang, W. Qi, M. Goodfellow, Int. J. Syst. Evol. Microbiol. 51, 319 (2001) 20. A. Pandey, P. Trivedi, B. Kumar, L. Palni, Curr. Microbiol. 53, 102 (2006)

21. A. Buch, G. Archana, K. Naresh, Res. Microbiol. 159, 635 (2008)

22. A. Gulati, P. Rahi, P. Vyas, Curr. Microbiol. 56, 73 (2008)

23. I. Reyes, A. Valery, Z. Valduz, Plant Soil. 287, 69 (2006) 